\title{
ERRATUM
}

\section{Erratum to: Analysis of differences in nutrients chemistry in seamount seawaters in the Kocebu and M5 seamounts in Western Pacific Ocean*}

\author{
Jun MA ${ }^{1,2,3,4}$, Jinming $\operatorname{SONG}^{1,2,3,4, * *}$, Xuegang $\mathrm{LI}^{1,2,3,4, * *}$, Qidong WANG ${ }^{1,2,3,4}$, \\ Huamao YUAN ${ }^{1,2,3,4}$, Ning LI ${ }^{1,2,3,4}$, Liqin DUAN ${ }^{1,2,3,4}$ \\ ${ }^{I}$ CAS Key Laboratory of Marine Ecology and Environmental Sciences, Institute of Oceanology, Chinese Academy of Sciences, \\ Qingdao 266071, China \\ ${ }^{2}$ Laboratory for Marine Ecology and Environmental Science, Qingdao National Laboratory for Marine Science and Technology, \\ Qingdao 266237, China \\ ${ }^{3}$ University of Chinese Academy of Sciences, Beijing 100049, China \\ ${ }^{4}$ Center for Ocean Mega-Science, Chinese Academy of Sciences, Qingdao 266071, China
}

(C) Chinese Society for Oceanology and Limnology, Science Press and Springer-Verlag GmbH Germany, part of Springer Nature 2021

\section{Erratum to: https://doi.org/10.1007/s00343-020-0239-7}

The HTML page of this article contains a few mistakes regarding the seamount names in the title and the abstract. The correct ones are as follows (the PDF within the DOI is also correct):

\section{Analysis of differences in nutrients chemistry in seamount seawaters in the Kocebu and M4 seamounts in Western Pacific Ocean*}

\begin{abstract}
Comprehensive surveys were conducted in the Kocebu deep seamount and the M4 shallow seamount in the Western Pacific Ocean in March 2018 and May 2019, respectively. The distributions of nutrients in euphotic zone of the two seamount-areas were revealed, and the causative controlling factors were analyzed. Results show that the vertical distribution of nutrients in the two seamount-areas accorded with the general law of the oligotrophic ocean. The concentrations of $\mathrm{NO}_{3}-\mathrm{N}, \mathrm{PO}_{4}-\mathrm{P}$, and $\mathrm{SiO}_{3}-\mathrm{Si}$ generally increased gradually with the increase of water depth, and they were extremely low in water layers within $100 \mathrm{~m}$. The area of high $\mathrm{NO}_{2}-\mathrm{N}$ concentration well agreed with the Deep Chlorophyll Maximum Layer. On the other hand, the distribution of water masses and phytoplankton and hydrological conditions in the two seamount-areas were different, resulting in lower concentrations of $\mathrm{NO}_{3}-\mathrm{N}, \mathrm{PO}_{4}-\mathrm{P}$, and $\mathrm{SiO}_{3}-\mathrm{Si}$ in the water layers below $100 \mathrm{~m}$ in the Kocebu seamount area than those in the $\mathrm{M} 4$ seamount area. In addition, $\mathrm{NO}_{2}-\mathrm{N}$ was affected by the distribution of phytoplankton, and distributed mainly in the water layers of 150 and $100 \mathrm{~m}$. There was upwelling in the euphotic zone of M4 seamount area, causing accumulations of nutrients and phytoplankton around the seamount, forming a "seamount effect"; however, no such an effect was found in Kocebu seamount area. Affected by the composition of biological community and the "seamount effect", the nitrogen limitation in the M4 seamount area was not significant, and the dissolved inorganic nitrogen (DIN): $\mathrm{PO}_{4}-\mathrm{P}$ and $\mathrm{SiO}_{3}-\mathrm{Si}$ :DIN were closer to the Redfield ratios.
\end{abstract}

The online version of the original articles can be found at: https://doi.org/10.1007/s00343-020-0239-7

\footnotetext{
* Supported by the Science \& Technology Basic Resources Investigation Program of China (No. 2017FY100802), the Strategic Priority Research Program of the Chinese Academy of Sciences (No. XDA19060401), and the National Natural Science Foundation of China (No. 91958103)

**Corresponding authors: jmsong@qdio.ac.cn; lixuegang@qdio.ac.cn
} 